\title{
Chronic Graft-Versus-Host Disease
}

\author{
Daniel Wolff and Anita Lawitschka
}

\subsection{Introduction}

Chronic GVHD (cGVHD) is the most relevant cause of late non-relapse morbidity and subsequent mortality (approximately 25\%) following allo-HSCT (Grube et al. 2016). Its incidence is approximately $50 \%$ among all patients following allo-HSCT and has increased during the last two decades due to increasing patient age and increasing use of unrelated and/or mismatched donors, RIC regimens, and PBSC (Arai et al. 2015). While the incidence of cGVHD is lower (20$40 \%$ ) in children, its incidence rises to $60 \%$ as age increases (Baird et al. 2010).

The pathophysiology of cGVHD is different from aGVHD and mainly characterized by impaired immune tolerance mechanisms affecting innate and adaptive immunity. Both autoreactive and alloreactive donor-derived $\mathrm{T}$ and $\mathrm{B}$ cells play a role (Cooke et al. 2017). Other pathophysiological factors are indirect presentations of alloantigens through antigen-presenting donor cells and mechanisms of chronic inflammation with subsequent scar formation and fibrosis. One important aspect of GVHD pathophysiology is the variability of immune reconstitution, which is

D. Wolff

Department of Internal Medicine III, University Hospital Regensburg, Regensburg, Germany

A. Lawitschka $(\bowtie)$

St. Anna Children's Hospital, Medical University

Vienna, Vienna, Austria

e-mail: anita.lawitschka@stanna.at age-related and dependent on thymic function and hormones. This adds to the unpredictability of the effects of transplant procedures and complications in a very heterogenous cohort of children and adolescents with malignant and nonmalignant diseases.

Known risk factors for adult and pediatric cGVHD are unrelated and/or mismatched donor, PBSCs as donor source, older donor age, female donor into male recipient, and the use of total body irradiation (Baird et al. 2010). By far the strongest predictor is the history and severity of acute GVHD.

In addition to the harm it causes, cGVHD also has a protective effect, as patients with cGVHD have lower rates of recurrence of their underlying malignant disease (Grube et al. 2016). Overall survival of patients transplanted for malignant diseases developing mild cGVHD is therefore better compared to patients without cGVHD. Even OS of patients with moderate cGVHD is not different from patients without cGVHD, as the slightly increased mortality associated with cGVHD is counterbalanced by lower disease-associated mortality (Kuzmina et al. 2012).

In contrast, the long-term mortality rate of patients with severe cGVHD is as high as $50 \%$ taken into account that the severity is less relevant compared to certain risk factors for mortality consisting of low platelets at diagnosis of cGVHD, the direct progression of acute GVHD into cGVHD (progressive onset), and certain organ manifestations 
(lung, gastrointestinal and cholestatic liver involvement) (Grube et al. 2016). One important pediatric aspect involves the high proportion (up to 50\%) of nonmalignant underlying diseases as HSCT indication. While malignant diseases benefit from the graft-versus-malignancy effect induced by GVHD, it only offers harm for the nonmalignant diseases. In daily clinical routine, this fact influences GVHD prophylaxis and treatment both in regard to intensity and duration of immunosuppressants (Lawitschka et al., data of a survey by the EBMT pediatric diseases WP, submitted). However, prospective pediatric data of immune reconstitution in GVHD patients evaluating the influence of underlying diseases are scarce.

\subsection{Clinical Manifestations}

cGVHD usually begins between 3 months and 2 years after HSCT, but earlier onset (at least 1 month after transplantation) is possible (Jagasia et al. 2015). Besides classical manifestations, cGVHD can imitate almost any autoimmune disease, such as myasthenia gravis and myositis. As cGVHD can affect a number of organs, and patients often do not report changes until functional impairment is recognized, regular examination of all organs potentially affected is essential. The following section describes the most common clinical organ manifestations of cGVHD. In general, pediatric manifestations are similar to adult cGVHD; when indicated, specific aspects are shortly described.

\subsubsection{Skin}

The skin is the most frequently involved organ with different morphology, depending on the different skin layers (epidermis, cutis, subcutis, and fasciae) involved. Some manifestations may overlap with acute GVHD like erythema, maculopapular rash, and pruritus. Cutaneous cGVHD may show many different non-sclerotic and sclerotic phenotypes often simulating well-known chronic inflammatory and autoimmune diseases (Strong Rodrigues et al. 2018).

Diagnostic features of NIH-defined cGVHD include poikiloderma, lichen planus-like, lichen sclerosus-like, morphea-like, and deep sclerotic eruptions, and no biopsy is needed to confirm the diagnosis. Distinctive for cGVHD, other or common skin manifestations like depigmentation and papulosquamous lesions or ichthyosis, keratosis pilaris, pigmental changes, loss of skin appendages, and sweat impairment are not sufficient for diagnosis and require histopathological confirmation if no diagnostic signs in the skin or other organs are present (Jagasia et al. 2015).

In pediatric patients, the incidence of viral reactivation and infection seems higher (although only proven for some viruses), and therefore infection has to be ruled out. Viral skin infections can worsen or activate cGVHD (Jacobsohn 2010). Premature graying of the hair is even in small children common, possibly together with seborrheic scalp changes. Of note, if sweat glands are destroyed, this may be of importance for phototherapy because of the inability to sweat with consequent hyperthermia.

\subsubsection{Eyes}

cGVHD of the eyes usually manifests as keratitis sicca. In addition to atrophy of the lacrimal gland with subsequent tear deficiency (sicca syndrome), the meibomian glands and eyelids are often affected by severe blepharitis which may initially present with tearing. Around the conjunctiva there are often not only fibrotic alterations but also chronic persistent inflammation with visible erythema of the conjunctiva. As dry eye symptoms are rarely communicated by children, light sensitivity is the predominant symptom, sometimes with excessive eye rubbing. Infections have to be ruled out. Referral to a pediatric experienced ophthalmologist is recommended.

\subsubsection{Oral Mucosa}

Oral manifestations may appear as erythema or lichenoid changes (the latter are regarded as diagnostic) of the oral mucosa as well as ulcera and mucoceles. Sicca symptoms may result from destruction of the salivary glands. Long-term cGVHD may lead to gingivitis, periodontitis, increased tooth decay, and tooth loss. In children 
excessive drinking during eating may be the first symptom of oral involvement. Not only mucosal problems but abnormal teeth development (e.g., hypodontia, root malformation, enamel hypoplasia) and caries are often seen as secondary symptoms in infants.

\subsubsection{Liver}

Liver involvement manifests as cholestasis and may resemble primary biliary cirrhosis, but hepatitic forms with high transaminases are also possible. Other factors, such as viral infections (hepatitis A, B, C, and E, CMV, EBV, ADV, and HHV6/7), drug toxicity, or total-parenteral nutrition-related cholestasis, should be excluded, but liver biopsy may be required to confirm the diagnosis, particularly in patients with no other symptoms of cGVHD and failure to respond to initial treatment of suspected GVHD (Stift et al. 2014).

\subsubsection{Gastrointestinal Tract}

GI manifestations can lead to dysphagia (esophagus), nausea and vomiting (stomach), or chronic diarrhea and malabsorption syndrome (intestines, pancreas). Occasionally cGVHD may also manifest as immune-mediated pancreatitis. Of note, except esophageal involvement, intestinal involvement is regarded as manifestation of acute GVHD, and patients are therefore classified as suffering from overlap syndrome in which concomitant symptoms of chronic and acute GVHD occur.

Infections like ADV or CMV gastroenteritis, secondary gluten or lactose intolerance, pancreatic insufficiency, and drug-related side effects (e.g., mycophenolate mofetil) have to be ruled out.

Malnutition and enteral fluid and protein loss in small children require regular laboratory monitoring.

\subsubsection{Genitals}

The symptoms of cGVHD are similar to those of genital lichen planus which may occur in males and females. Vaginal synechiae, ulceration, and fissures can subsequently occur. Genital manifestations are often associated with oral manifestations of cGVHD. As symptoms may not be reported spontaneously, females suffering from cGVHD require regular gynecological follow-up. In girls cGVHD may manifest with vulvovaginitis, in boys with balanitis or balanoposthitis. Of note, healing may occur with fibrosis possibly leading to synechia with the risk of hematocolpos during puberty in females and of phimosis in males.

\subsubsection{Lung}

Pulmonary manifestations occur as progressive, irreversible obstruction (bronchiolitis obliterans) and less frequently lymphocytic alveolitis resulting in interstitial fibrosis or bronchiolitis obliterans organizing pneumonia (BOOP) (see Chap. 52).

Since the onset of pulmonary symptoms may not be symptomatic and obstruction may be irreversible, regular evaluations of a serial pulmonary function test (PFT) with body plethysmography (from the age of 4-6 years on) and diffusion capacity (usually from 8-10 years of age on) are required in asymptomatic patients.

While interstitial fibrosis is well known after lung transplant (restrictive allograft syndrome), prospective data after allogeneic HSCT are lacking, but case reports indicate that restrictive immune-mediated lung disease after allo-HSCT may occur.

Patients require follow-up by a pediatric experienced pulmonologist. Of note, the possible overlap of (1) myopathy/hypotrophy of the respiratory muscles (glucocorticoid induced, \pm central obesity, and/or physical inactivity), (2) restriction of the chest wall in the context of dermal sclerosis, and (3) unproportional chest growth after TBI and/or local irradiation may contribute with a restrictive ventilator dysfunction leading to a mixed picture.

Finally, a thorough diagnostic evaluation includes a lung CT scan and a BAL to rule out viral, bacterial, fungal, and mycobacterial infections.

Coexisting IgA deficiency and chronic sinusitis or sinubronchial syndrome should be considered in the diagnostic workup (Hildebrandt et al. 2011). 


\subsubsection{Joints and Fasciae}

cGVHD-associated fasciitis (diagnostic for cGVHD) can result in restricted mobility of joints. This can also be caused by deep cutaneous sclerosis. Moreover, rheumatoid complaints may be associated with cGVHD. In children myositis, muscle weakness, cramping, edema, and pain are quite common. However, iatrogenic glucocorticoid-induced myopathy may overlap with fasciitis. Range-ofmotion (ROM) examinations are recommended at baseline and at serial intervals with the P-ROM scale providing an easy-to-apply tool. (There is a pediatric adaption, ped P-ROM; see addendum).

\subsection{Diagnosis}

cGVHD is diagnosed on the basis of cGVHD symptoms of eight organs, laboratory values (for hepatic manifestations), and PFTs. Each organ is graded between 0 and 3 . The overall severity of cGVHD is classified as mild, moderate, or severe based on this organ-specific grading (number of organs and severity). Overall severity is calculated on the basis of the number of organs affected and the severity of their involvement. Only in case that functional involvement is solely due to none GVHD causes the impairment is not scored (Jagasia et al. 2015). Biomarkers of cGVHD are currently explored but require validation before clinical use.

\subsubsection{Organ Grading of cGVHD for Adults and Children (See Annex 1 and Addendum)}

\subsubsection{Grading of Overall Severity of cGVHD (Jagasia et al. 2015)}

\begin{tabular}{ll|l|l|}
$\begin{array}{l}\text { Overall } \\
\text { severity }\end{array}$ & Mild & Moderate & Severe \\
\hline $\begin{array}{l}\text { Number of } \\
\text { involved } \\
\text { organs }\end{array}$ & $1-2$ & $\geq 3$ & $\underline{3}$ \\
$\begin{array}{l}\text { Severity of } \\
\text { involved } \\
\text { organs }\end{array}$ & $\begin{array}{l}\text { Mild } \\
\text { (excluding } \\
\text { lung) }\end{array}$ & $\begin{array}{l}\text { Mild- } \\
\text { moderate } \\
\text { (lung only } \\
\text { mild) }\end{array}$ & $\begin{array}{l}\text { Severe (lung } \\
\text { moderate or } \\
\text { severe) }\end{array}$ \\
\hline
\end{tabular}

If diagnostic symptoms of cGVHD are absent, histological confirmation of diagnosis may be required. This may be particularly the case in gastrointestinal, nonspecific cutaneous, hepatic, and pulmonary manifestations to rule out toxic or infectious causes or comorbidity. Clinicopathologic series indicate a significant risk for inappropriate diagnosis and subsequent treatment if diagnosis has been made solely by clinical manifestations (and lacking diagnostic symptoms) without histological confirmation.

\subsection{Treatment}

\subsubsection{First-Line Therapy}

First-line treatment (see Table 44.1) consists of steroids given alone or in combination with CNI and is based on randomized trials.

As mild cGVHD does not impair organ function, the use of topical IS (topical steroids, topical CNI, or phototherapy) should be considered. If this is impossible, PRD treatment at an initial dose of $0.5-1 \mathrm{mg} / \mathrm{kg}$ body weight/day is recommended. Topical IS can be used in addition to systemic IS, to improve efficacy, or to reduce systemic IS, but lack systemic efficacy.

For moderate or severe $c G V H D$, systemic treatment with PRD or methylPRD at an initial dose of $1 \mathrm{mg} / \mathrm{kg}$ body weight/day should be used. In individual cases lower doses of $0.5-1 \mathrm{mg} /$ $\mathrm{kg}$ may be used (Jacobsohn 2010). The combination of steroids with a CNI (CSA or TAC) is particularly worth considering for severe cGVHD. Rituximab has been explored in firstline treatment of cGVHD in combination with steroids and CNI demonstrating an increased response rate on the expense of an increased risk for late infectious complications and delayed B-cell recovery. Currently, ECP and ibrutinib are evaluated in first-line treatment of cGVHD within randomized clinical trials.

As cGVHD often takes time to respond to IS treatment, response should not be assessed until at least 8 weeks have elapsed or until 3-6 months have elapsed in the presence of deep cutaneous sclerosis. Long-term IS treatment lasting at least 3-6 months is often required. Dose reduction of IS agents should be performed stepwise. 
Table 44.1 First-line treatment of cGVHD

\begin{tabular}{|c|c|c|c|c|c|}
\hline \multirow[b]{2}{*}{ Drug } & \multicolumn{2}{|c|}{ Recommendation } & \multirow{2}{*}{$\begin{array}{l}\text { Side effects in }>25 \% \\
\text { patients }\end{array}$} & \multirow{2}{*}{$\begin{array}{l}\text { Response } \\
\text { rate }\end{array}$} & \multirow[b]{2}{*}{ Comment } \\
\hline & Grade & Evidence & & & \\
\hline Steroids & A & I & $\begin{array}{l}\text { Osteoporosis, } \\
\text { osteonecrosis, diabetes } \\
\text { mellitus }\end{array}$ & $\begin{array}{l}\sim 30-50 \% \\
\mathrm{CR}\end{array}$ & $\begin{array}{l}\text { Main drug; strategies to reduce use } \\
\text { due to SEs very important }\end{array}$ \\
\hline $\mathrm{CNI}+$ steroids & C-1 & II & $\begin{array}{l}\text { Renal toxicity, } \\
\text { hypertension }\end{array}$ & $\begin{array}{l}\sim 30-50 \% \\
\mathrm{RC}\end{array}$ & $\begin{array}{l}\text { Reduces steroid use, reduced } \\
\text { incidence of osteonecrosis }\end{array}$ \\
\hline $\begin{array}{l}\text { Rituximab + } \\
\text { steroids/CNI }\end{array}$ & $\mathrm{C}-1$ & III- $1^{12}$ & $\begin{array}{l}\text { Increased risk for late } \\
\text { infectious complications }\end{array}$ & $\sim 75 \%$ & Randomized data are lacking \\
\hline $\begin{array}{l}\mathrm{MMF}+\mathrm{CNI} / \\
\text { steroids }\end{array}$ & $\mathrm{D}$ & II & $\begin{array}{l}\text { GI complaints, } \\
\text { infections }\end{array}$ & & $\begin{array}{l}\text { No increased efficacy compared to } \\
\text { CNI and steroids, increased risk of } \\
\text { relapse of malignancy }\end{array}$ \\
\hline Azathioprine & $\mathrm{D}$ & II & $\begin{array}{l}\text { Cytopenia, risk of } \\
\text { infection }\end{array}$ & & Increased mortality \\
\hline Thalidomide & D & II & $\begin{array}{l}\text { Neurotoxicity, } \\
\text { drowsiness, constipation }\end{array}$ & & Very little effect in first-line therapy \\
\hline
\end{tabular}

Adapted from Wolff et al. (2011), A: should always be used; C-1: use in first-line therapy justified, D: moderate evidence of lack of efficacy or unacceptably high risks, should generally not be offered, I: evidence from $\geq 1$ properly randomized, controlled trials, II: evidence from more than one well-planned non-randomized clinical trial, from cohort or case-controlled, analytic studies (preferably at several sites), III-1: only one non-controlled study, III-2: only one retrospective, non-controlled study or retrospective evaluation. (Evidence and recommendations graded according to the 2005 NIH Consensus), SE side effect, NIH US National Institutes of Health, MMF mycophenolate mofetil

Depending on the patient population, first-line therapy achieves complete remission of cGVHD in approximately 20\% (adults) to 50\% (children) of cases. If symptoms progress during the first 4 weeks of first-line therapy or there is no improvement in symptoms within 8-12 weeks, second-line therapy should be initiated.

\subsubsection{Topical Therapy and Supportive Care}

In principle, there is no difference between cGVHD treatment for children and adults. However, longterm steroid therapy in children causes major side effects in terms of growth, bone density, osteonecrosis, and organ development, making agents that reduce steroid use, entailing the use of topical drugs, particularly important. Age-based ancillary supportive care is essential in the management of pediatric cGVHD with the chance of sparing systemic therapy, often supported by highly compliant parents and/or family members as caregivers (Carpenter et al. 2015). In small children, the risk of systemic effects of topical steroid and CNI treatment must be considered. cGVHD is by itself remarkably immunosuppressive intensified by its treatment (especially high-dose corticosteroids) leading to a high risk for infections: (a) for viral reactivation like CMV, $\mathrm{ADV}$, and $\mathrm{EBV}$ and (b) for fungal infection like candida and aspergillosis. Functional asplenia with occurrence of HowellJolly bodies and a higher incidence of pneumococcal sepsis has to be considered also. Breakdown of skin and mucosal barriers adds to this risk.

Revaccinations (see Chap. 29) with inactivated vaccines are strongly recommended after consolidation of cGVHD (Hilgendorf et al. 2011). Live vaccines should be avoided in this patient population. Ursodeoxycholic acid reduced liver GVHD and improved survival (Ruutu et al. 2014). Supplemental IVIG replacement is recommended in cGVHD patients with $\mathrm{IgG}<400 \mathrm{mg} / \mathrm{dL}$ or recurrent infections which is of special importance in children but does also apply to adults. In case of long-term substitution or the history of anaphylactic reactions, we prefer to substitute subcutaneously.

\subsubsection{Second-Line Therapy}

While first-line therapy is based on randomized trials, second-line therapy mostly is based on phase II trials, and retrospective analyses are available (see Table 44.2). In addition, because 
Table 44.2 Second-line treatment of cGVHD

\begin{tabular}{|c|c|c|c|c|c|}
\hline \multirow[b]{2}{*}{ Drug } & \multicolumn{2}{|c|}{ Recommendation } & \multirow[b]{2}{*}{ Response rate } & \multirow{2}{*}{$\begin{array}{l}\text { Side effects in }>25 \% \\
\text { of patients }\end{array}$} & \multirow[b]{2}{*}{ Comments } \\
\hline & Grade & Evidence & & & \\
\hline Steroids & B & III-1 & n.a. & $\begin{array}{l}\text { Osteoporosis, } \\
\text { osteonecrosis, diabetes } \\
\text { mellitus }\end{array}$ & $\begin{array}{l}\text { Main drug, strategies to } \\
\text { reduce use due to SEs very } \\
\text { important }\end{array}$ \\
\hline Ibrutinib & $\mathrm{C}-1$ & III-1 & $\begin{array}{l}\sim 50-75 \% \\
\sim 16-25 \% \mathrm{CR}\end{array}$ & $\begin{array}{l}\text { Bruising, diarrhea, } \\
\text { infections }\end{array}$ & $\begin{array}{l}\text { FDA approved in second-line } \\
\text { treatment of cGVHD }\end{array}$ \\
\hline Photophereses & C-1 & II & $\begin{array}{l}\sim 60-70 \% \\
\sim 30 \% \mathrm{CR}\end{array}$ & $\begin{array}{l}\text { Infections of the CVC } \\
\text { (if applicable) }\end{array}$ & $\begin{array}{l}\text { Venous access required, } \\
\text { steroid-saving effect, good } \\
\text { tolerability }\end{array}$ \\
\hline $\begin{array}{l}\text { mTOR-inh } \\
\text { (sirolimus, } \\
\text { everolimus) }\end{array}$ & $\mathrm{C}-1$ & III-1 & $\begin{array}{l}\sim 60 \% \\
\sim 20 \% \mathrm{CR}\end{array}$ & $\begin{array}{l}\text { TMA, hyperlipidemia, } \\
\text { cytopenia }\end{array}$ & $\begin{array}{l}\text { Increased risk of TMA when } \\
\text { combined with CNI, regular } \\
\text { blood levels required }\end{array}$ \\
\hline MMF & $\mathrm{C}-1$ & III-1 & $\begin{array}{l}\sim 50 \% \\
\sim 10 \% \mathrm{CR}\end{array}$ & $\begin{array}{l}\text { GI SEs, risk of } \\
\text { infection (viral) and } \\
\text { increased risk of } \\
\text { relapse }\end{array}$ & Steroid sparing activity \\
\hline $\mathrm{CNI}$ & $\mathrm{C}-1$ & III-1 & n.a. & $\begin{array}{l}\text { Renal toxicity, } \\
\text { hypertension }\end{array}$ & $\begin{array}{l}\text { Reduces steroid use, regular } \\
\text { blood levels required }\end{array}$ \\
\hline MTX & $\mathrm{C}-2$ & III-1 & $\begin{array}{l}\sim 50 \% \\
\sim 10-20 \% \mathrm{CR}\end{array}$ & Cytopenia & $\begin{array}{l}\text { Best results in mucocutaneous } \\
\text { cGVHD, reduces steroid use, } \\
\text { contraindicated in the } \\
\text { presence of pleural effusions } \\
\text { or ascites }\end{array}$ \\
\hline IL-2 & $\mathrm{C}-2$ & III-1 & $\begin{array}{l}\sim 65 \% \text { (only } \\
\text { PR) }\end{array}$ & $\begin{array}{l}\text { Fever, malaise, and } \\
\text { fatigue }\end{array}$ & $\begin{array}{l}\text { Applied in sclerodermoid skin } \\
\text { disease }\end{array}$ \\
\hline Ruxolitinib & $\mathrm{C}-2$ & III-1 & $\begin{array}{l}\text { n.a. } \\
\text { (retrospective } \\
\text { analysis) }\end{array}$ & $\begin{array}{l}\text { Increased risk for viral } \\
\text { reactivation, bacterial } \\
\text { infection, } \\
\text { hepatotoxicity }\end{array}$ & Prospective data pending \\
\hline Bortezomib & $\mathrm{C}-2$ & III-1 & $\begin{array}{l}\text { n.a. for } \\
\text { second-line } \mathrm{Tx}\end{array}$ & Cytopenia, neuropathy & $\begin{array}{l}\text { Trial was performed in } \\
\text { first-line treatment }\end{array}$ \\
\hline High-dose steroids & $\mathrm{C}-2$ & III-2 & $\begin{array}{l}50-75 \% \\
\text { (only PR) }\end{array}$ & Infections & Rapid control of cGVHD \\
\hline $\begin{array}{l}\text { Total nodal } \\
\text { irradiation }\end{array}$ & $\mathrm{C}-2$ & III-2 & $\begin{array}{l}\sim 50 \% \\
\sim 25 \% \mathrm{CR}\end{array}$ & Cytopenia & $\begin{array}{l}\text { Best results for fasciitis and } \\
\text { mucocutaneous cGVHD }\end{array}$ \\
\hline Hydroxychloroquine & $\mathrm{C}-2$ & III-2 & $\begin{array}{l}\sim 25 \% \\
\sim 10 \% \mathrm{CR}\end{array}$ & GI side effects & $\begin{array}{l}\text { Best results for } \\
\text { mucocutaneous and hepatic } \\
\text { cGVHD }\end{array}$ \\
\hline Pentostatin & $\mathrm{C}-2$ & II & $\begin{array}{l}\sim 50 \% \\
\sim 10 \% \mathrm{CR}\end{array}$ & $\begin{array}{l}\text { Cytopenia, risk of } \\
\text { infection }\end{array}$ & Best results in children \\
\hline Rituximab & $\mathrm{C}-2$ & II & $\begin{array}{l}\sim 50 \% \\
\sim 10 \% \mathrm{CR}\end{array}$ & Risk of infection & $\begin{array}{l}\text { Effective in manifestations } \\
\text { associated with autoAb and } \\
\text { sclerodermoid cutaneous } \\
\text { involvement }\end{array}$ \\
\hline Imatinib & $\mathrm{C}-2$ & III-1 & $\begin{array}{l}\sim 50 \% \\
\sim 20 \% \mathrm{CR}\end{array}$ & Fluid retention & $\begin{array}{l}\text { Efficacy demonstrated mainly } \\
\text { in sclerodermoid cGVHD and } \\
\text { bronchiolitis obliterans }\end{array}$ \\
\hline Thalidomide & $\mathrm{C}-3$ & II & $\begin{array}{l}\sim 20-30 \% \text { (only } \\
\text { PR) }\end{array}$ & $\begin{array}{l}\text { Neurotoxicity, } \\
\text { drowsiness, } \\
\text { constipation }\end{array}$ & $\begin{array}{l}\text { Treatment for simultaneous } \\
\text { cGVHD and recurrent } \\
\text { multiple myeloma }\end{array}$ \\
\hline
\end{tabular}


Table 44.2 (continued)

\begin{tabular}{|c|c|c|c|c|c|}
\hline \multirow[b]{2}{*}{ Drug } & \multicolumn{2}{|c|}{ Recommendation } & \multirow[b]{2}{*}{ Response rate } & \multirow{2}{*}{$\begin{array}{l}\text { Side effects in }>25 \% \\
\text { of patients }\end{array}$} & \multirow[b]{2}{*}{ Comments } \\
\hline & Grade & Evidence & & & \\
\hline Azathioprine & C-3 & III-1 & n.a. & $\begin{array}{l}\text { Cytopenia, risk of } \\
\text { infection, secondary } \\
\text { malignancies }\end{array}$ & $\begin{array}{l}\text { Increased risk of malignant } \\
\text { disease of the oral mucosa }\end{array}$ \\
\hline Retinoids & $\mathrm{C}-3$ & III-2 & $\begin{array}{l}\sim 60 \% \text { (only } \\
\text { PR) }\end{array}$ & $\begin{array}{l}\text { Skin toxicity, } \\
\text { hyperlipidemia }\end{array}$ & $\begin{array}{l}\text { Effective in sclerodermoid } \\
\text { cutaneous involvement }\end{array}$ \\
\hline Abatacept & $\mathrm{C}-3$ & III-2 & $\sim 40 \%$ & & $\begin{array}{l}\text { Effective in mucocutaneous } \\
\text { and pulmonary involvement }\end{array}$ \\
\hline Regulatory $\mathrm{T}$ cells & C-4 & & & & $\begin{array}{l}\text { Currently explored in several } \\
\text { clinical trials }\end{array}$ \\
\hline $\begin{array}{l}\text { Mesenchymal stem } \\
\text { cells }\end{array}$ & C-4 & III-2 & n.a. & & $\begin{array}{l}\text { Repetitive application } \\
\text { required }\end{array}$ \\
\hline Alemtuzumab & C-4 & III-3 & n.a. & Infectious risks & $\begin{array}{l}\text { Last resort for refractory } \\
\text { cGVHD }\end{array}$ \\
\hline Etanercept & C-4 & III-3 & n.a. & Infectious risks & $\begin{array}{l}\text { May be used to treat mixed } \\
\text { acute and chronic GVHD or } \\
\text { pulmonary or GI } \\
\text { manifestations of cGVHD }\end{array}$ \\
\hline
\end{tabular}

Adapted from Wolff et al. (2011), B: should generally be used, C-1: use in second-line therapy justified, C-2: use after failure of second-line therapy justified, C-3: should only be used in specific circumstances, due to unfavorable risk profile, C-4: experimental, should only be used in clinical trials and individual cases, II: evidence from $>1$ well-designed clinical trial without randomization, from cohort or case-controlled analytic studies (preferable from $>1$ center) or from multiple time series, III-1: several reports from retrospective evaluations or small uncontrolled clinical trials, III-2: only one report from small uncontrolled clinical trial or retrospective evaluations, III-3: only case reports available, SE: side effect, n.a.: not available

the data on disease severity and patient populations are very heterogeneous (in terms of age, conditioning, and stem cell source), the published response rates cannot be fully extrapolated to the majority of patients currently treated for cGVHD. Moreover, many substances have been used almost exclusively in combination with steroids.

In general, no more than three IS agents should be combined, as combinations of more drugs often does not lead to improved efficacy but results in a significantly increased risk of side effects and infections. Because of the substantial toxicity of long-term steroid treatment, strategies for dose reduction are very important. Since no predictors of response for a single agent in individual patients are yet available, the choice of agent depends mainly on side effect profiles and patients' medical history. The response rates for specific agents range between $20 \%$ and $70 \%$ (photopheresis).

Certain drugs such as imatinib and retinoids are recommended only for manifestations associated with sclerosis (bronchiolitis obliterans [imatinib], sclerodermoid cutaneous alterations [retinoids, imatinib]), because of their specific mechanisms of action.

Response is assessed as for first-line therapy. Administration of drugs that have been shown to be ineffective should be stopped. As a rule, drugs shown to be ineffective should be tapered off stepwise with no more than one drug to be changed at a time in order to be able to evaluate their efficacy. 


\section{Appendix 1}

Annex 1 - Organ Scoring of Chronic GVHD

\begin{tabular}{|c|c|c|c|c|}
\hline & SCORE 0 & SCORE 1 & SCORE 2 & SCORE 3 \\
\hline $\begin{array}{l}\text { PERFORMANCE SCORE: } \\
\text { KPS ECOG LPS }\end{array}$ & $\begin{array}{l}\text { Asymptomatic } \\
\text { and fully active } \\
\text { (ECOG 0; KPS or } \\
\text { LPS } 100 \% \text { ) }\end{array}$ & $\begin{array}{l}\text { Symptomatic, } \\
\text { fully ambulatory, } \\
\text { restricted only in } \\
\text { physically } \\
\text { strenuous } \\
\text { activity (ECOG 1, } \\
\text { KPS or LPS } 80- \\
90 \% \text { ) }\end{array}$ & $\begin{array}{l}\text { Symptomatic, } \\
\text { ambulatory, } \\
\text { capable of self-care, } \\
>50 \% \text { of waking } \\
\text { hours out of bed } \\
\text { (ECOG } 2, \text { KPS or LPS } \\
60-70 \%)\end{array}$ & $\begin{array}{l}\text { Symptomatic, } \\
\text { limited self- } \\
\text { care, }>50 \% \text { of } \\
\text { waking hours in } \\
\text { bed (ECOG } 3-4 \text {, } \\
\text { KPS or LPS } \\
<60 \% \text { ) }\end{array}$ \\
\hline $\begin{array}{l}\text { SKIN† } \\
\text { SCORE \%BSA }\end{array}$ & & & & \\
\hline $\begin{array}{l}\text { GVHD features to be } \\
\underline{\text { scored }} \\
\text { by BSA: } \\
\text { Check all that applies: } \\
\text { Maculopapular } \\
\text { rash/erythema } \\
\square \text { Lichen planus-like } \\
\text { features } \\
\square \text { Sclerotic features } \\
\square \text { Papulosquamous } \\
\text { lesions or ichthyosis } \\
\square \text { Keratosis pilaris-like } \\
\text { GVHD }\end{array}$ & $\square$ No BSA involved & $\square 1-18 \% \mathrm{BSA}$ & $\square 19-50 \%$ BSA & $\square>50 \%$ BSA \\
\hline $\begin{array}{l}\text { SKIN FEATURES } \\
\text { SCORE: }\end{array}$ & $\begin{array}{l}\square \text { No sclerotic } \\
\text { features }\end{array}$ & & $\begin{array}{l}\square \text { Superficial } \\
\text { sclerotic features } \\
\text { "not hidebound" } \\
\text { (able to pinch) }\end{array}$ & $\begin{array}{l}\text { Check all that } \\
\text { applies: } \\
\square \text { Deep sclerotic } \\
\text { features } \\
\square \text { "Hidebound" } \\
\text { (unable to pinch) } \\
\square \text { Impaired mobility } \\
\square \text { Ulceration }\end{array}$ \\
\hline $\begin{array}{l}\text { Other skin GVHD featur } \\
\text { Check all that applies: } \\
\square \text { Hyperpigmentation } \\
\square \text { Hypopigmentation } \\
\square \text { Poikiloderma } \\
\square \text { Severe or generalized } \\
\square \text { Hair involvement } \\
\square \text { Nail involvement }\end{array}$ & (NOT scored by BSA & & & \\
\hline \multicolumn{5}{|c|}{$\square$ Abnormality present but explained entirely by non-GVHD documented cause (specify): } \\
\hline $\begin{array}{l}\text { MOUTH } \\
\text { Lichen planus-like } \\
\text { features present: } \\
\square \text { Yes } \\
\square \text { No }\end{array}$ & $\square$ No symptoms & $\begin{array}{l}\square \text { Mild symptoms } \\
\text { with disease signs } \\
\text { but not limiting oral } \\
\text { intake significantly }\end{array}$ & $\begin{array}{l}\text { Moderate } \\
\text { symptoms with } \\
\text { disease signs with } \\
\text { partial limitation of } \\
\text { oral intake }\end{array}$ & $\begin{array}{l}\text { Severe symptoms } \\
\text { with disease signs } \\
\text { on examination } \\
\text { with major } \\
\text { limitation of oral } \\
\text { intake }\end{array}$ \\
\hline
\end{tabular}

$\square$ Abnormality present but explained entirely by non-GVHD documented cause (specify): 
Annex 1 - Organ Scoring of Chronic GVHD (continued)

\begin{tabular}{|c|c|c|c|c|}
\hline & SCORE 0 & SCORE 1 & SCORE 2 & SCORE 3 \\
\hline $\begin{array}{l}\text { EYES } \\
\text { Keratoconjunctivitis } \\
\text { sicca (KCS) } \\
\text { confirmed by } \\
\text { Ophthalmologist: } \\
\square \text { Yes } \\
\square \text { No } \\
\square \text { Not examined }\end{array}$ & $\square$ No symptoms & $\begin{array}{l}\square \text { Mild dry eye } \\
\text { symptoms not } \\
\text { affecting } A D L \\
\text { (requirement of } \\
\text { lubricant eye } \\
\text { drops } \leq 3 \times \text { per } \\
\text { day) }\end{array}$ & $\begin{array}{l}\text { Moderate dry eye } \\
\text { symptoms } \\
\text { partially affecting } \\
\text { ADL (requiring } \\
\text { lubricant eye } \\
\text { drops }>3 \times \text { per } \\
\text { day or punctal } \\
\text { plugs), WITHOUT } \\
\text { new vision } \\
\text { impairment due } \\
\text { to KCS }\end{array}$ & $\begin{array}{l}\text { Severe dry eye } \\
\text { symptoms } \\
\text { significantly } \\
\text { affecting ADL } \\
\text { (special eyeware } \\
\text { to relieve pain) } \\
\text { OR unable to } \\
\text { work because of } \\
\text { ocular symptoms } \\
\text { OR loss of vision } \\
\text { due to KCS }\end{array}$ \\
\hline \multicolumn{5}{|c|}{$\square$ Abnormality present but explained entirely by non-GVHD documented cause (specify): } \\
\hline $\begin{array}{l}\text { GI TRACT } \\
\text { Check all that } \\
\text { applies: } \\
\square \text { Esophageal web/ } \\
\text { proximal stricture or } \\
\text { ring } \\
\square \text { Dysphagia } \\
\square \text { Anorexia } \\
\square \text { Nausea } \\
\square \text { Vomiting } \\
\square \text { Diarrhea } \\
\square \text { Weight loss* } \\
\square \text { Failure to thrive }\end{array}$ & $\square$ No symptoms & $\begin{array}{l}\text { Symptoms } \\
\text { without } \\
\text { significant } \\
\text { weight loss* } \\
(<5 \%)\end{array}$ & $\begin{array}{l}\text { Symptoms } \\
\text { associated with } \\
\text { mild to moderate } \\
\text { weight loss* } \\
(5-15 \%) \text { OR } \\
\text { moderate } \\
\text { diarrhea without } \\
\text { significant } \\
\text { interference of } \\
\text { daily living }\end{array}$ & $\begin{array}{l}\text { Symptoms } \\
\text { associated with } \\
\text { significant weight } \\
\text { loss }^{*}>15 \%, \\
\text { requires nutritional } \\
\text { supplement for } \\
\text { most calorie } \\
\text { needs OR } \\
\text { esophageal } \\
\text { dilation OR } \\
\text { severe diarrhea } \\
\text { with significant } \\
\text { interference of } \\
\text { daily living }\end{array}$ \\
\hline \multicolumn{5}{|c|}{$\square$ Abnormality present but explained entirely by non-GVHD documented cause (specify): } \\
\hline LIVER & $\begin{array}{l}\text { Normal total } \\
\text { bilirubin and ALT } \\
\text { or AP } \\
<3 \times \text { ULN } \\
\end{array}$ & $\begin{array}{l}\text { Normal total } \\
\text { bilirubin with ALT } \\
\geq 3 \text { to } 5 \times \text { ULN or } \\
\text { AP }>3 \times \text { ULN }\end{array}$ & $\begin{array}{l}\square \text { Elevated total } \\
\text { bilirubin but } \\
\leq 3 \mathrm{mg} / \mathrm{dL} \text { or } \\
\mathrm{ALT}>5 \text { ULN }\end{array}$ & $\begin{array}{l}\square \text { Elevated total } \\
\text { bilirubin }>3 \\
\mathrm{mg} / \mathrm{dL}\end{array}$ \\
\hline \multicolumn{5}{|c|}{$\square$ Abnormality present but explained entirely by non-GVHD documented cause (specify): } \\
\hline $\begin{array}{l}\text { LUNGS }^{\star *} \\
\text { Symptoms score }\end{array}$ & $\square$ No symptoms & $\begin{array}{l}\square \text { Mild symptoms } \\
\text { (shortness of } \\
\text { breath after } \\
\text { climbing one flight } \\
\text { of steps) }\end{array}$ & $\begin{array}{l}\square \text { Moderate } \\
\text { symptoms } \\
\text { (shortness of } \\
\text { breath after } \\
\text { walking on flat } \\
\text { ground) }\end{array}$ & $\begin{array}{l}\text { Severe symptoms } \\
\text { (shortness of } \\
\text { breath at rest; } \\
\text { requiring } \mathrm{O}_{2} \text { ) }\end{array}$ \\
\hline Lung score: & $\square$ FEV1 $\geq 80 \%$ & $\square$ FEV1 60-79 & $\square$ FEV1 40-59\% & $\square$ FEV1 $\leq 39 \%$ \\
\hline FEV1 & & & & \\
\hline \multicolumn{5}{|c|}{$\begin{array}{l}\text { Pulmonary function tests } \\
\square \text { Not performed }\end{array}$} \\
\hline$\square$ Abnormality prese & explained entirely & GVHD documented & (specify): & \\
\hline
\end{tabular}


Annex 1. Organ scoring of chronic GVHD (continued)

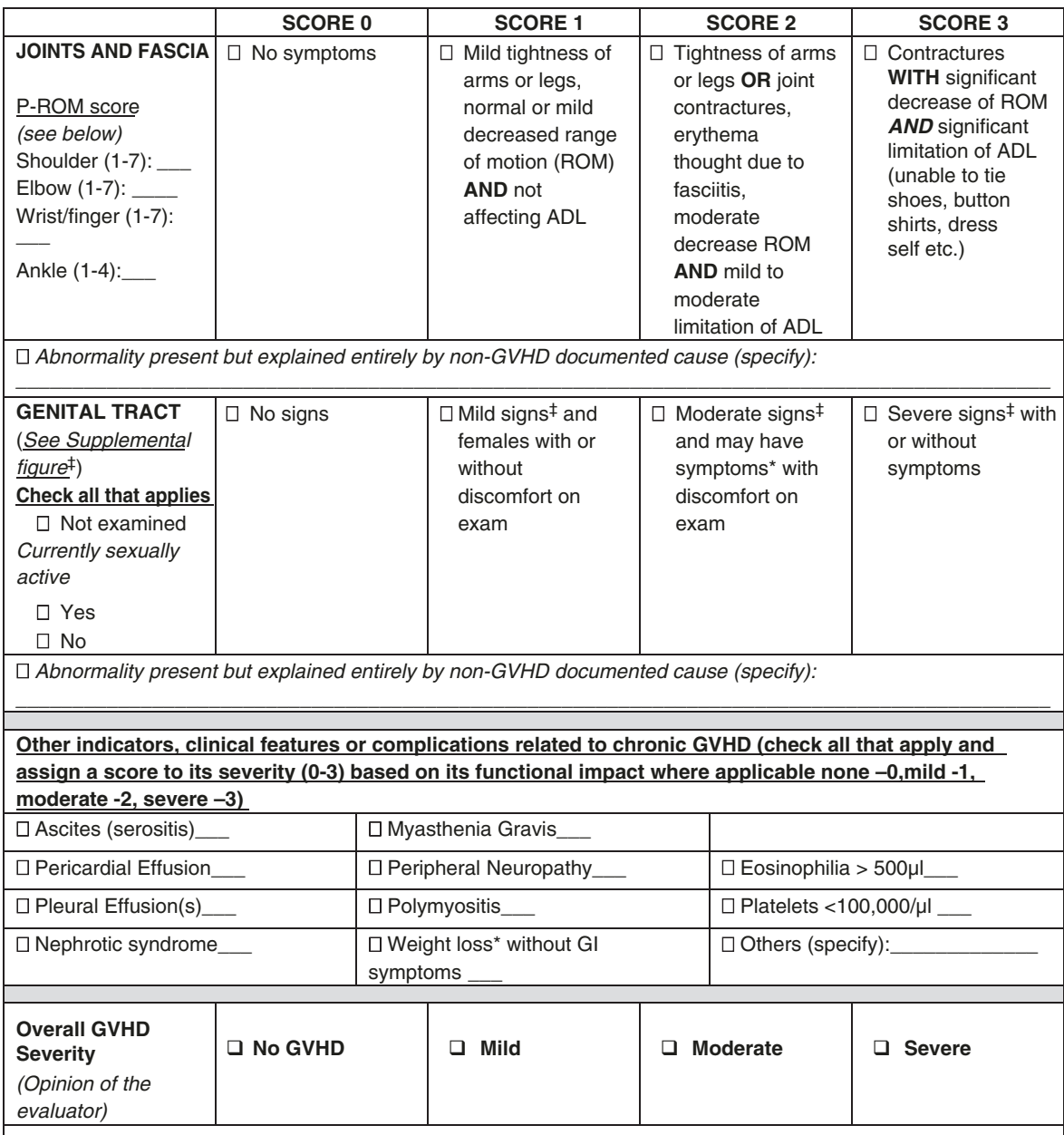

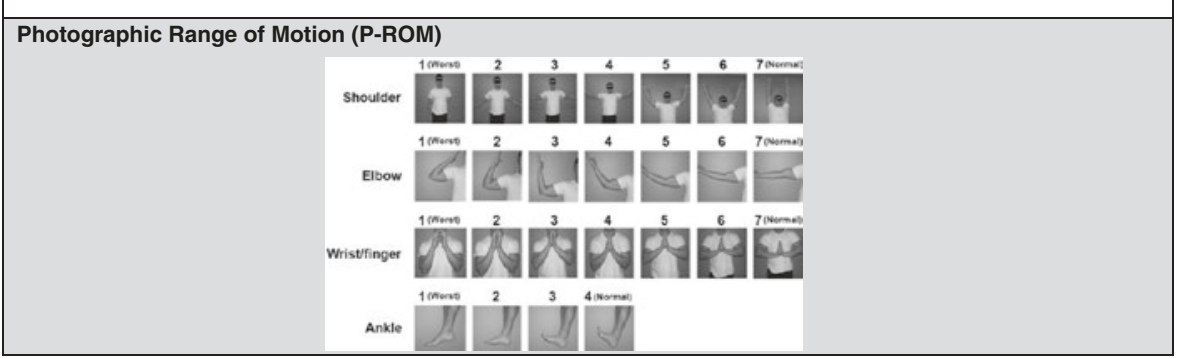

Adapted from Jagasia, 2015.

† Skin scoring should use both percentage of BSA involved by disease signs and the cutaneous features scales. When a discrepancy exists between the percentage of total body surface (BSA) score and the skin feature score, OR if superficial sclerotic features are present (Score 2), but there is impaired mobility or ulceration (Score 3), the higher level should be used for the final skin scoring.

* Weight loss within 3 months.

** Lung scoring should be performed using both the symptoms and FEV1 scores whenever possible. FEV1 should be used in the final lung scoring where there is discrepancy between symptoms and FEV1 scores. Abbreviations: ECOG (Eastern Cooperative Oncology Group), KPS (Karnofsky Performance Status), LPS (Lansky Performance Status); BSA (body surface area); ADL (activities of daily living); LFTs (liver function tests); AP (alkaline phosphatase); ALT (alanine aminotransferase); NUL (normal upper limit).

¥ To be completed by specialist or trained medical providers (see Supplemental Figure). 


\section{Appendix 2}

\section{Diagnosis and staging cGVHD in children}

Jagasia et al BBMT 2015

pediatric adaptation A. Lawitschka 11/2015

classification:actual

- please score/check the worst manifestation

- diagnostic features are marked bold patient name

date:

patient name $\square$ feat. of acute GVHD

$\square$ feat.of classic cGVHD

$\square$ both onset type ONLY at diagn.:

$\square$ de novo

$\square$ quiescent

$\square$ progressive

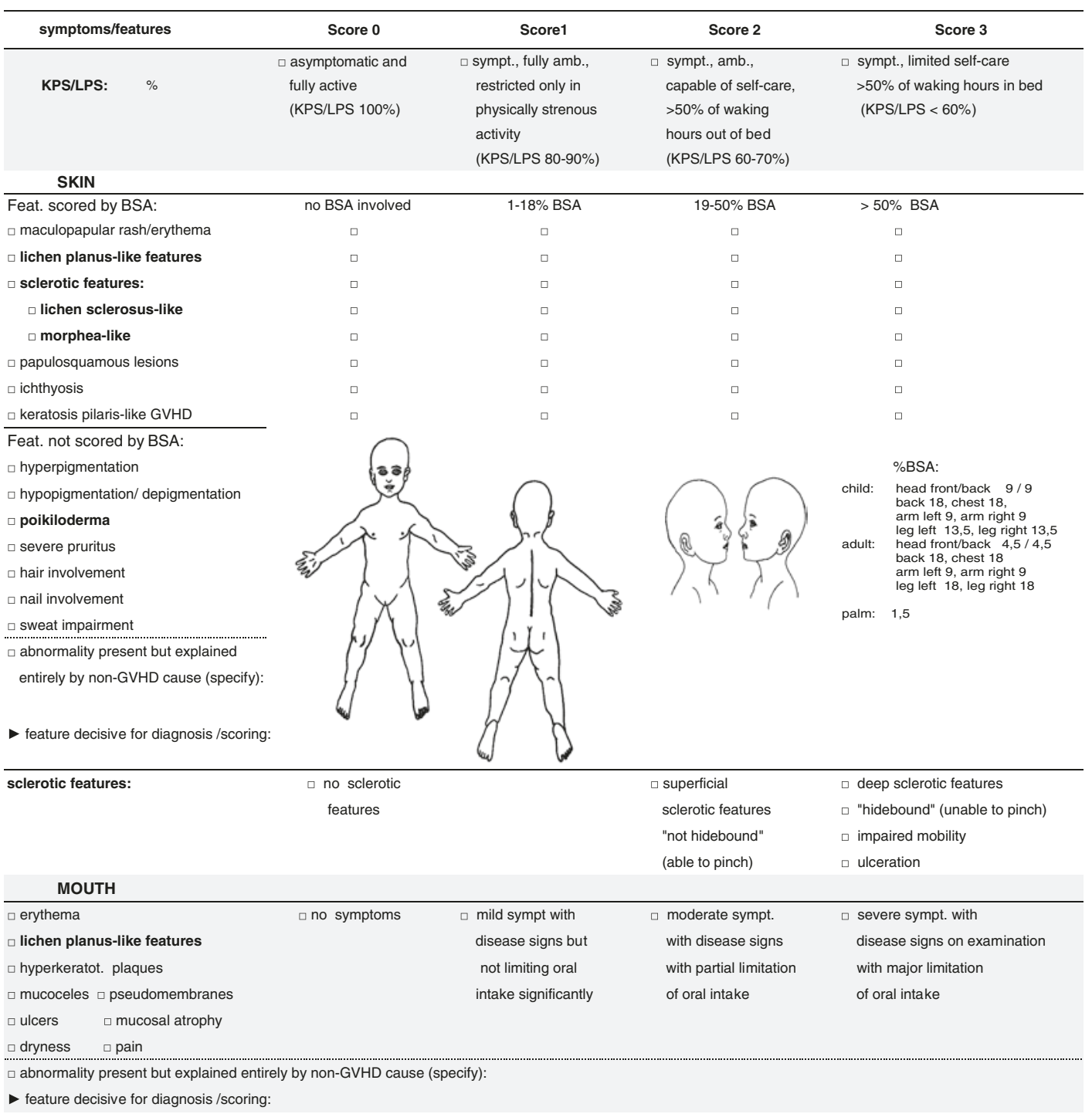


Appendix 2 - Diagnosis and staging cGVHD in children (continued)

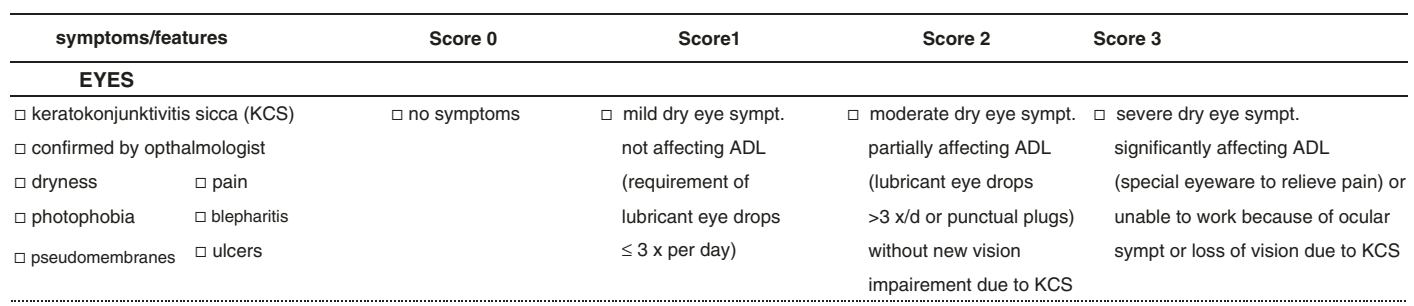

$\square$ abnormality present but explained entirely by non-GVHD cause (specify):

- feature decisive for diagnosis /scoring:

GI TRACT

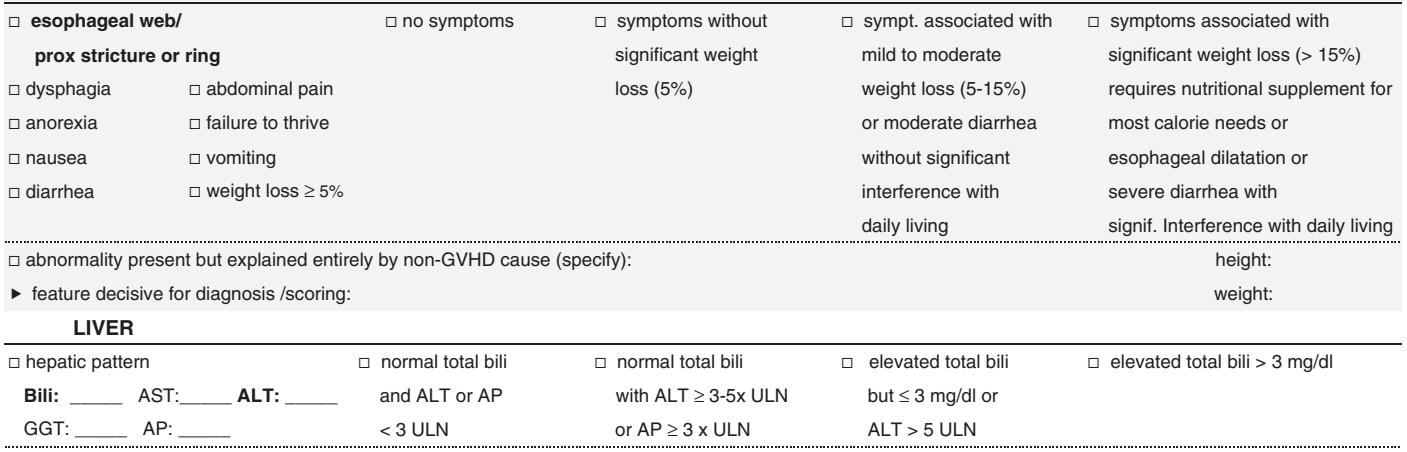

$\checkmark$ abnormality present but explained entirely by non-GVHD cause (specify):

- feature decisive for diagnosis /scoring:

\section{LUNGS}

\begin{tabular}{|c|c|c|c|c|c|c|}
\hline FEV1: & $\%$ & MEF25:__ $\%$ & $\square$ no symptoms & $\square$ mild symptoms & $\square$ moderate symptoms & $\square$ severe symptoms \\
\hline FVC: & $-\%$ & MEF50:__ $\%$ & FEV $1 \geq 80 \%$ & (shortness of breath & (shortness of breath & (shortness of breath at rest; \\
\hline DLCO: & - \% & MEF75:___ $\%$ & & after climbing one & after walking on & requiring $\mathrm{O} 2$ ) \\
\hline RV: & & $\square R V / T L C>120 \%$ & & flight of steps) & flat ground) & FEV1 $\leq 39 \%$ \\
\hline CT: & & & & FEV1 $\quad 60-79 \%$ & FEV1 $\quad 40-59 \%$ & \\
\hline
\end{tabular}

$\square$ abnormality present but explained entirely by non-GVHD cause (specify):

- feature decisive for diagnosis /scoring:

JOINTS AND FASCIA

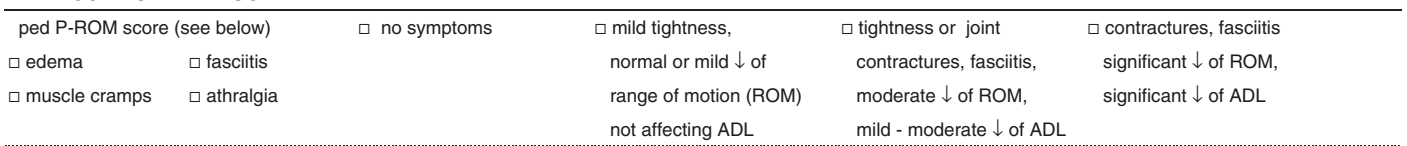

$\square$ abnormality present but explained entirely by non-GVHD cause (specify)

- feature decisive for diagnosis /scoring: GENITAL TRACT

口 erosions, fissures $\quad \square$ no signs $\quad \square$ mild signs $\quad \square$ moderate signs $\quad \square$ severe signs with or without

$\square$ lichen planus-like features symptoms

$\square$ lichen sclerosus-like features

$\square$ labial/ vaginal scarring $\square$ phimosis

$\square$ abnormality present but explained entirely by non-GVHD cause (specify)

- feature decisive for diagnosis /scoring:

\section{Overall GVHD severity}

$\square$ no cGVHD

$\square$ mild: $\quad$ max. score of 1 in any affected organ, max. 2 organs affected, no lung involvement

$\square$ moderate: $\quad \geq 3$ organ with max score 1 or max. score of 2 in any affected organ, lung score max 1

$\square$ severe: $\quad$ score 3 in any affected organ, lung score 2-3 
Appendix 2 - Diagnosis and staging cGVHD in children (continued)

Other indicators, clinical features or complications related to cGVHD

biopsy:

check all that apply and assign a severity score (0-3) based on functional impact

organ:

$\square$ ascites (serositis)

$\square$ myasthenia gravis

$\square$ eosinophilia $>500$ /ul

GVHD confirmed?

$\square$ pericardial effusion

$\square$ peripheral neuropathy

$\square$ platelets $<100000 / u l$

$\square$ pleural effusion

$\square$ polymyositis

$\square$ nephrotic syndrome

$\square$ weight loss $>5 \%$ without Gl sympt

$\square$ hypo/hyperglobulinemia

$\square$ others (specify)

$\square$ diabetes

$\square$ auto-antibodies

pediatric photographic range of motion (adapted ped P-ROM):

please mark appropriate number

shoulder:
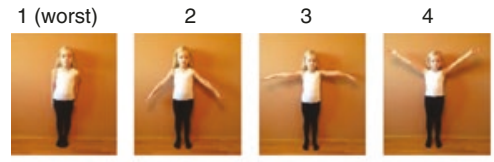

5 (normal)

ellbow:

1 (worst)

2

3

4 (normal)
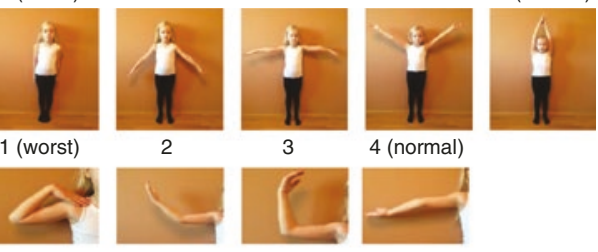

wrist / finger:

1 (worst)

2

3

4 (normal)

global flexion:
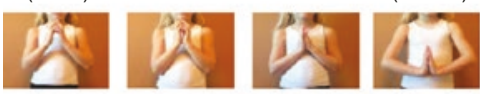

3

4 (normal)

ankle:
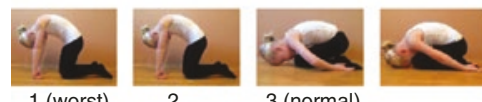

1 (worst)

2

3 (normal)

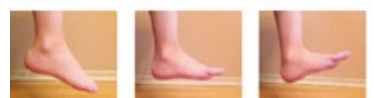




\section{Appendix 3}

\section{Genital Tract GVHD Assessment and Scoring Form}

Name:

Date of birth:

Assessment date:

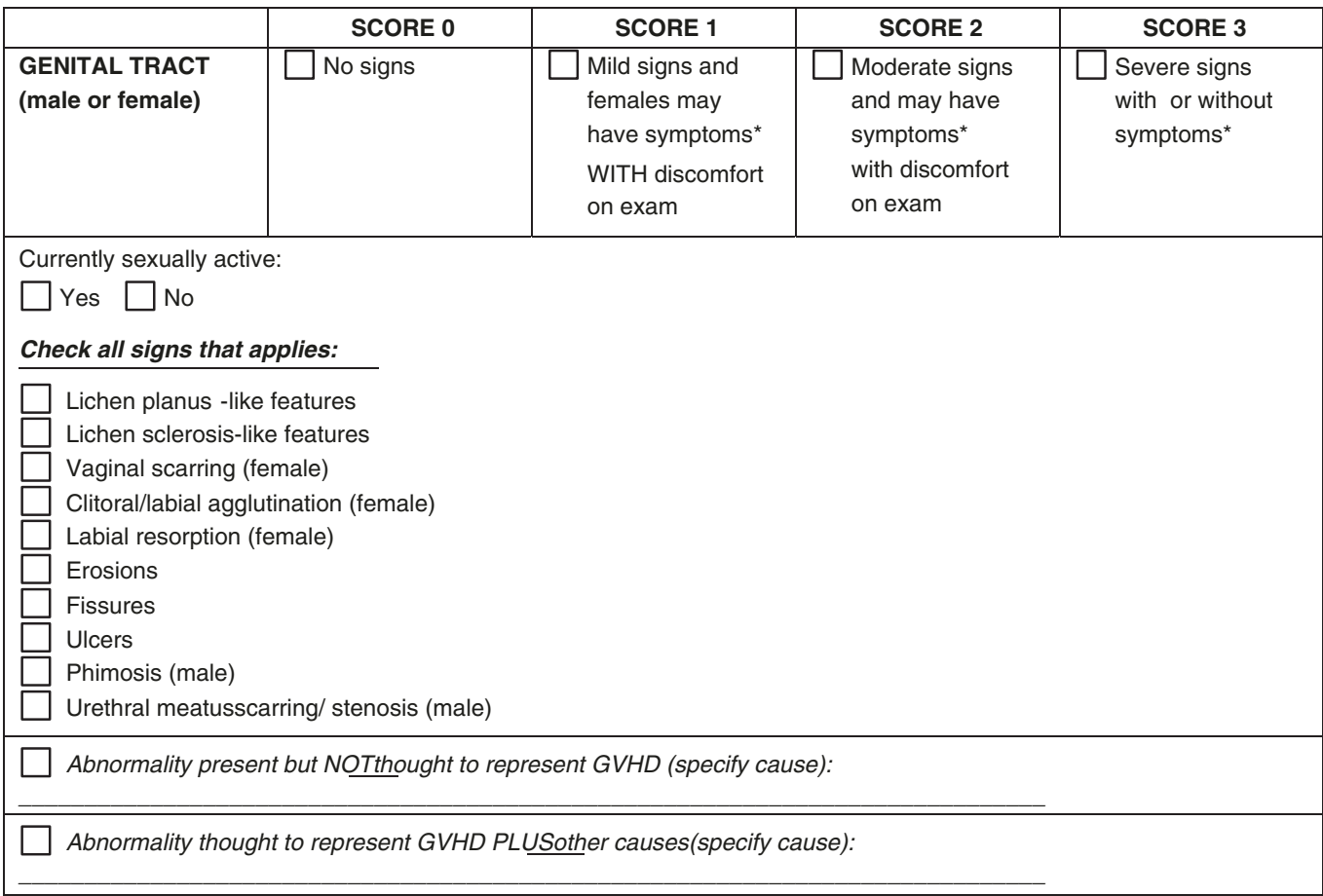

* Genital symptoms are not specific to cGVHD and can represent premature gonadal failure or genital tract infection.

If a gynecologist is unavailable, external examination may be performed to determine "discomfort on exam" as follows:

a) Spread the labia majora to inspect the vulva for the above signs. Touch the vestibular gland openings (Skene's and Bartholin's), labia minora and majora gently with a qtip. Vulvar pain elicited by the gentle touch of a qtip is classified as discomfort on examination. Palpate the vaginal walls with a single digit to detect bands, shortening, narrowing or other signs of vaginal scarring.

b) If the woman is sexually active, determine whether qtip palpation or gentle palpation of scarred ridges elicits pain similar to that which the woman experiences during intercourse.

Female genitalia: Severity of signs:

1) Mild (any of the following); erythema on vulvar mucosal surfaces, vulvar lichen-planus or vulvar lichen-sclerosis.

2) Moderate (any of the following); erosive inflammatory changes of the vulvar mucosa, fissures in vulvar folds.

3) Severe (any of the following); labial fusion, clitoral hood agglutination, fibrinous vaginal adhesions, circumferential fibrous vaginal banding, vaginal shortening, synechia, dense sclerotic changes, and complete vaginal stenosis.

Male genitalia: Diagnostic features include lichen planus-like or lichen sclerosis-like features and phymosis or urethral scarring or stenosis. Severity of signs:

1) Mild: lichen planus-like feature;

2) Moderate: lichen sclerosis-like feature or moderate erythema;

3) Severe: phimosis or urethral/meatal scarring.

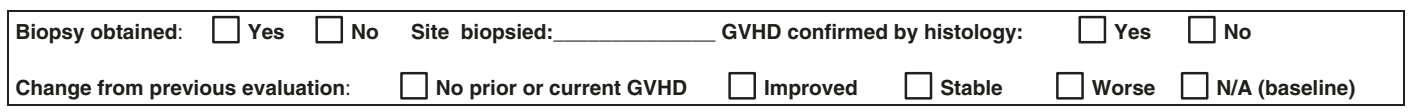

Completed by (spell out name):

Date form completed: 


\section{References}

Arai S, Arora M, Wang T, et al. Increasing incidence of chronic graft-versus-host disease in allogeneic transplantation: a report from the Center for International Blood and Marrow Transplant Research. Biol Blood Marrow Transplant. 2015;21:266-74.

Baird K, Cooke K, Schultz KR. Chronic graft-versushost disease (GVHD) in children. Pediatr Clin N Am. 2010;57:297-322.

Carpenter PA, Kitko CL, Elad S, et al. National Institutes of Health Consensus Development Project on criteria for clinical trials in chronic graft-versus-host disease: V. The 2014 Ancillary Therapy and Supportive Care Working Group Report. Biol Blood Marrow Transplant. 2015;21:1167-87.

Cooke KR, Luznik L, Sarantopoulos S, et al. The biology of chronic graft-versus-host disease: A Task Force Report from the National Institutes of Health Consensus Development Project on criteria for clinical trials in chronic graft-versus-host disease. Biol Blood Marrow Transplant. 2017;23:211-34.

Grube M, Holler E, Weber D, et al. Risk factors and outcome of chronic graft-versus-host disease after allogeneic stem cell transplantation-results from a single-center observational study. Biol Blood Marrow Transplant. 2016;22:1781-91.

Hildebrandt GC, Fazekas T, Lawitschka A, et al. Diagnosis and treatment of pulmonary chronic GVHD: report from the consensus conference on clinical practice in chronic GVHD. Bone Marrow Transplant. 2011;46:1283-95.

Hilgendorf I, Freund M, Jilg W, et al. Vaccination of allogeneic haematopoietic stem cell transplant recipients: report from the international consensus conference on clinical practice in chronic GVHD. Vaccine. 2011;29:2825-33.

Jacobsohn DA. Optimal management of chronic graftversus-host disease in children. $\mathrm{Br} \mathrm{J}$ Haematol. 2010;150:278-92.

Jagasia MH, Greinix HT, Arora M, et al. National Institutes of Health Consensus Development Project on Criteria for Clinical Trials in Chronic Graft-versus-Host Disease: I. The 2014 Diagnosis and Staging Working Group report. National Institutes of Health Consensus Development Project on Criteria for Clinical Trials in Chronic Graft-versus-Host Disease: I. Biol Blood Marrow Transplant. 2015;21:389.e1-401.e1.

Kuzmina Z, Eder S, Bohm A, et al. Significantly worse survival of patients with NIH-defined chronic graftversus-host disease and thrombocytopenia or progressive onset type: results of a prospective study. Leukemia. 2012;26:746-56.

Ruutu T, Juvonen E, Remberger M, et al. Improved survival with ursodeoxycholic acid prophylaxis in allogeneic stem cell transplantation: long-term follow-up of a randomized study. Biol Blood Marrow Transplant. 2014;20:135-8.

Stift J, Baba HA, Huber E, et al. Consensus on the histopathological evaluation of liver biopsies from patients following allogeneic hematopoietic cell transplantation. Virchows Arch. 2014;464:175-90.

Strong Rodrigues K, Oliveira-Ribeiro C, de Abreu Fiuza Gomes S, Knobler R. Cutaneous graft-versus-host disease: diagnosis and treatment. Am J Clin Dermatol. 2018;19:33-50.

Wolff D, Bertz H, Greinix H, et al. The treatment of chronic graft-versus-host disease: consensus recommendations of experts from Germany, Austria, and Switzerland. Dtsch Arztebl Int. 2011;108:732-40.

Open Access This chapter is licensed under the terms of the Creative Commons Attribution 4.0 International License (http://creativecommons.org/licenses/by/4.0/), which permits use, sharing, adaptation, distribution and reproduction in any medium or format, as long as you give appropriate credit to the original author(s) and the source, provide a link to the Creative Commons license and indicate if changes were made.

The images or other third party material in this chapter are included in the chapter's Creative Commons license, unless indicated otherwise in a credit line to the material. If material is not included in the chapter's Creative Commons license and your intended use is not permitted by statutory regulation or exceeds the permitted use, you will need to obtain permission directly from the copyright holder. 